\title{
Aquatic Contamination of the Turvo Limpo River Basin at the Minas Gerais State, Brazil
}

\author{
Cláudio P. Jordão, ${ }^{*, a}$ Paulo Roberto da S. Ribeiro, ${ }^{b}$ Antônio T. de Matos ${ }^{c}$ and Raphael B. A. Fernandes ${ }^{a}$ \\ ${ }^{a}$ Departamento de Solos, ${ }^{b}$ Departamento de Química and ${ }^{c}$ Departamento de Engenharia Agrícola, \\ Universidade Federal de Viçosa, 36570-000 Viçosa-MG, Brazil
}

\begin{abstract}
Foi desenvolvido um estudo para avaliar a contaminação aquática provinda de descargas de esgotos municipais, tratados ou inadequadamente tratados, como também provindas de áreas de pastagem, de agricultura, de depósitos de resíduos de construção civil e de sucata metálica, nas vizinhanças da bacia do Rio Turvo Limpo. Os cursos d'água examinados foram o Ribeirão São Bartolomeu, o Rio Turvo Sujo e o Rio Turvo Limpo, localizados no Estado de Minas Gerais, Brasil. As amostras de água foram coletadas as margens dos cursos d'água nos meses de julho, agosto e setembro de 2005 , no período da estiagem, para se avaliar a presença de poluentes. Foram determinados nos cursos d'água o pH, oxigênio dissolvido, demanda bioquímica de oxigênio, fosfato total, série de nitrogênios (total, amoniacal e nitrato), e as concentrações de $\mathrm{Al}, \mathrm{Ca}, \mathrm{Cr}, \mathrm{Cu}, \mathrm{Fe}, \mathrm{Mg}, \mathrm{Ni}, \mathrm{Pb}$ e $\mathrm{Zn}$. As concentrações destes metais também foram determinadas nos sólidos em suspensão. Altas concentrações de $\mathrm{Zn}\left(15.350 \mathrm{mg} \mathrm{\textrm {kg } ^ { - 1 }}\right) \mathrm{e}$ de $\mathrm{Pb}\left(3.590 \mathrm{mg} \mathrm{kg}^{-1}\right)$ foram encontradas nos sólidos em suspensão, enquanto que nas águas do Ribeirão São Bartolomeu a concentração de Al atingiu $1.480 \mu \mathrm{g} \mathrm{L}^{-1}$. O valor de $\mathrm{pH}$ e as concentrações de demanda bioquímica de oxigênio, de fosfato total, e de nitrogênio amoniacal total nos cursos d'água mostraram-se fora dos valores de águas Classe 2, estabelecidos pela legislação ambiental brasileira. Em todos os pontos de amostragem ocorreram incrementos nas concentrações de nitrato, quando comparadas com a amostra coletada em uma fonte (sítio 1). As concentrações de nitrato ficaram abaixo das concentrações de nitrogênio amoniacal total, indicando que o nitrogênio nos cursos d'água foi originado principalmente de descargas recentes de esgoto, tendo em vista que não ocorreu mineralização expressiva com a formação de íons nitrato.
\end{abstract}

The aquatic contamination from the discharge of untreated or inadequately treated municipal sewage, as well as from husbandry, agriculture, and the disposal of municipal garbage, metallic scraps and civil architecture residues in the neighborhood of the Turvo Limpo River basin was evaluated. The water-courses examined were the São Bartolomeu Stream, Turvo Sujo River, and Turvo Limpo River, located in the Minas Gerais State, Brazil. Water samples were collected at the river-side in the dry season (July, August, and September 2005) and analyzed for evaluation of pollutant inputs. The $\mathrm{pH}$, dissolved oxygen (DO), biochemical oxygen demand (BOD), total phosphate, total ammonia nitrogen $\left(\mathrm{NH}_{3}+\mathrm{NH}_{4}^{+}\right)$, nitrate and metal concentrations ( $\mathrm{Al}, \mathrm{Ca}, \mathrm{Cr}, \mathrm{Cu}, \mathrm{Fe}, \mathrm{Mg}, \mathrm{Ni}, \mathrm{Pb}$, and $\mathrm{Zn}$ ) in water samples were determined. The concentrations of these metals in the suspended solids were also determined. The suspended solids showed high concentrations of $\mathrm{Zn}\left(15,350 \mathrm{mg} \mathrm{kg}^{-1}\right)$ and $\mathrm{Pb}\left(3,590 \mathrm{mg} \mathrm{kg}^{-1}\right)$, while the stream water was enhanced with $\mathrm{Al}\left(1,480 \mu \mathrm{g} \mathrm{L}^{-1}\right)$. The $\mathrm{pH}$ and the concentrations of BOD, total phosphate and total ammonia nitrogen in the watercourses were far from those established by the Brazilian Environmental Standards for Class 2 water. In all examined sites there was an increase in the nitrate concentration compared with that of a spring (site 1). The nitrate concentrations were below those of the total ammonia nitrogen, indicating that the nitrogen in the water-courses was mainly originated from recent sewage discharges, since did not occurred larger mineralization with the formation of nitrate ions.

Keywords: metal, water, suspended particle, contamination

*e-mail: jordao@ufv.br 


\section{Introduction}

The discharge of untreated or inadequately treated domestic sewage into aquatic environments can cause deleterious effects to health. The introduction of biodegradable organic matter in water systems decreases the level of dissolved oxygen, ${ }^{1}$ which is one of the more important parameters available in the field of water pollution control, as it permits the evaluation of the aerobic conditions of a water-course, which receives discharge of pollutants.

Although the discarded materials contain potential toxic constituents, few efforts to purify water have been conducted in the Turvo Limpo river basin at Minas Gerais State, Brazil. According to official data pertaining to the whole year of 2001, only $52.2 \%$ of the Brazilian municipal districts had conventional treatment of sewage effluents. ${ }^{2}$ Unfortunately, only $0.9 \%$ of the municipal districts at Minas Gerais State, Brazil, treat adequately sewage effluents. ${ }^{3}$

Efficient waste management practices that include potential hazard minimization, recovery operations and treatment prior to stream emissions should be implemented. Particularly, heavy metals and organic compounds need to be controlled at the source to enable use of sewage, for instance, in irrigation or groundwater recharge.

The contamination of water-courses can result in the water enrichment with nutrients, such as nitrogen and phosphorus. These nutrients cause excessive growth of algae, which compete with other aquatic organisms, at light absence conditions, for the dissolved oxygen. ${ }^{4}$

It has been reported that the metal transport in solution is of secondary importance since most of the metals analyzed in the Amazon River (Brazil) and in the Yukon River (Alaska) were carried mainly in the solid phase, from 65 to $92 \%$ of $\mathrm{Cr}, \mathrm{Mn}, \mathrm{Fe}, \mathrm{Co}, \mathrm{Ni}$, and $\mathrm{Cu}$ were transported via suspended solids. ${ }^{5}$

In view of the above, the objective of this work is to evaluate the water contamination caused by effluent discharges into the local water-courses. Thus, water samples were collected in Turvo Limpo river basin and analyzed in order to obtain metal concentrations $(\mathrm{Al}, \mathrm{Ca}, \mathrm{Cr}, \mathrm{Cu}, \mathrm{Fe}$, $\mathrm{Mg}, \mathrm{Ni}, \mathrm{Pb}$, and $\mathrm{Zn}$ ) in water and suspended solids, as well as the $\mathrm{pH}$, dissolved oxygen (DO), biochemical oxygen demand (BOD), total phosphate, total ammonia nitrogen $\left(\mathrm{NH}_{3}+\mathrm{NH}_{4}^{+}\right)$and nitrate levels. The data obtained were compared with the Brazilian Environmental Standards and with those of contaminated and non-contaminated areas.

\section{Experimental}

The region where the study was performed is located in south-eastern Brazil (Figure 1) and includes the Ribeirão
São Bartolomeu (São Bartolomeu Stream), the Rio Turvo Sujo (Turvo Sujo River) and the Rio Turvo Limpo (Turvo Limpo River). The region is far from industrialized areas, but it is heavily influenced by other anthropogenic inputs such as untreated or inadequately treated municipal sewage.

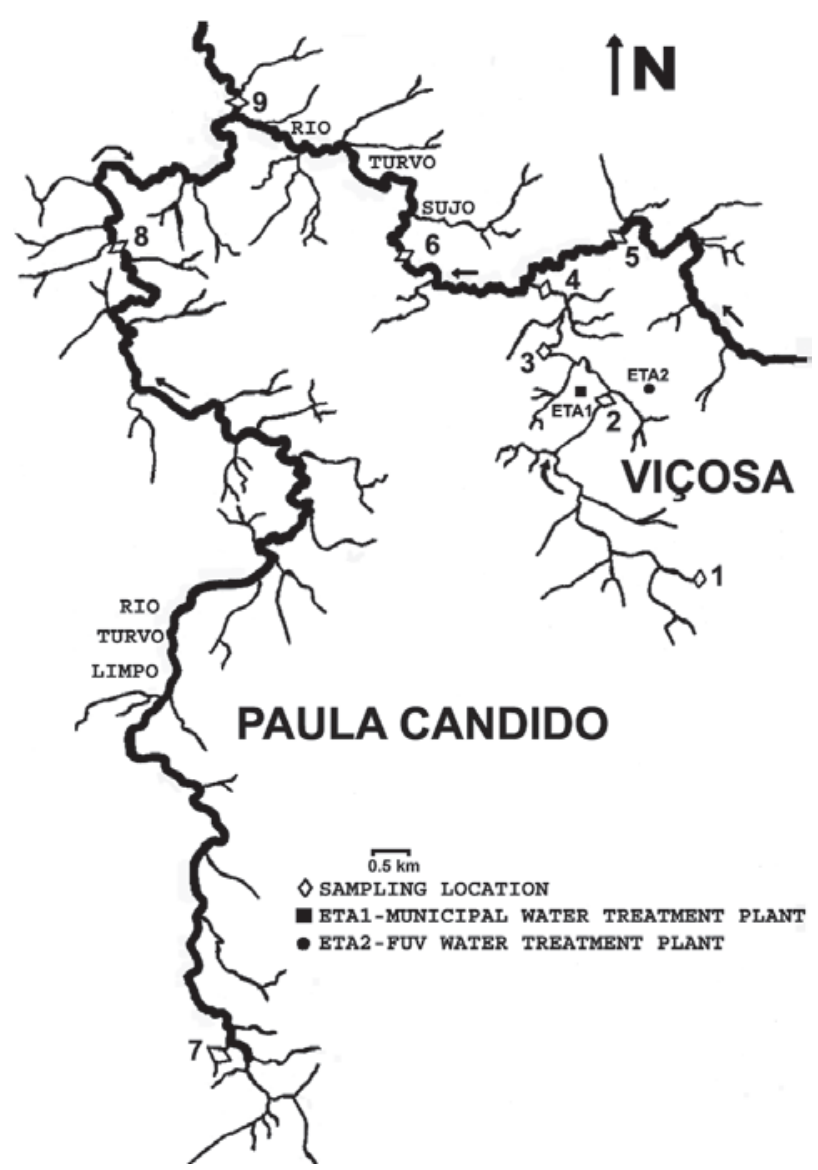

Figure 1. Location of sampling sites.

The sampling sites selected were situated in the city of Viçosa (71,000 inhabitants) and in the city of Paula Cândido (9,412 inhabitants) at the Minas Gerais State. The micro basin of the São Bartolomeu Stream comprises around 440 springs and integrates the Turvo Limpo River basin located in Viçosa. The São Bartolomeu Stream runs to the Turvo Sujo River while the latter runs to the Turvo Limpo River. The São Bartolomeu Stream cross the Federal University of Viçosa campus, which is located upstream the urban region of Viçosa. Five dams in the campus area of the São Bartolomeu Stream are responsible for the water supply of $70 \%$ of the inhabitants of Viçosa, as well as for irrigation, recreation and landscape purposes. ${ }^{6}$

The São Bartolomeu Stream microbasin region presents topography heavily uneven, with reduced portions of plain areas. The plain areas in the valleys have, in the 
bottom, a larger bed periodically flooded, whereas in the hill side there are asymmetrical terraces frequently used for agriculture practices and for houses construction. ${ }^{7}$ The processes of urban expansion as well as the implantation of husbandry and agriculture were responsible for the substitution of the native vegetation. Nowadays, the forests remains are constituted by secondary vegetation and obliterated in the tops of the hills. The climate of the region includes a dry winter and a rainy summer, with the temperatures varying from $18{ }^{\circ} \mathrm{C}$ to $22{ }^{\circ} \mathrm{C} .{ }^{8}$

The water samples were collected in the dry season at about $10 \mathrm{~cm}$ below the surface in bottles previously rinsed with deionized water and further with surface water before filling. For BOD, total ammonia nitrogen, nitrate and metals determinations the plastic bottles were previously soaked in diluted $\mathrm{HCl}$ and then rinsed with deionized water. For total phosphate determination, the samples were collected in glass bottles in order to avoid adsorption on the walls of polyethylene containers. The glass bottles were previously soaked in diluted $\mathrm{HNO}_{3}$ and then rinsed with deionized water. The collected water samples were refrigerated at $4{ }^{\circ} \mathrm{C}$ and analyzed within 24 hours. This is the correct procedure for non-preserved samples. ${ }^{9}$

The water samples for the metal determinations in the suspended particles and for nitrate determinations were filtered through a membrane filter of $0.45 \mu \mathrm{m}$ pore size. For the nitrate determinations, they were filtered because colorimetric methods require an optically clear sample. The filters were previously analyzed in respect to any contamination and the first $60 \mathrm{~mL}$ of each sample discharged. When necessary, the water samples were first filtered through a No. 2 glass sinter to separate the coarse material. Filtration was performed under vacuum in a Buchner funnel. The filtration apparatus was washed with deionized water before use.

The chemical and biochemical parameters of the watercourses were determined following the standard methods for the analysis of water and wastewater as follows. ${ }^{9}$

The $\mathrm{pH}$ of the water samples were measured immediately after sampling in a volume of $50 \mathrm{~mL}$ and introducing into the instrument cell of the portable equipment. The calibration of the equipment was performed in the field using buffer solutions of $\mathrm{pH} 4.0$ and 7.0.

The dissolved oxygen concentrations of the water samples were measured at the collecting sites using an oxygen-sensitive membrane electrode. The apparatus was previously calibrated using a mixed solution of sodium sulfite and cobalt chloride with dissolved oxygen concentration equal to zero. The apparatus was also calibrated for $100 \mathrm{mg} \mathrm{L}^{-1}$ of $\mathrm{O}_{2}$ with the electrode suspended in the air. The dissolved oxygen concentrations of the water samples were corrected for the altitude of the collection sites. The correction was calculated as described in the operation manual of the instrument used. For each $100 \mathrm{~m}$ above sea level, $1.1 \%$ was subtracted from the value observed on the apparatus display.

The $\mathrm{BOD}_{5}$ determination was conducted in the water samples based on the difference between the concentration of dissolved oxygen before and after incubating the samples at $20^{\circ} \mathrm{C}$ for 5 days. The $\mathrm{pH}$ values of the samples were corrected to between 6.5 and 7.5 with $\mathrm{H}_{2} \mathrm{SO}_{4}$ or $\mathrm{NaOH}$, when necessary.

The assessment of the dissolved oxygen concentration in the samples to the determination of BOD was carried out using the iodometry method, modified by the addition of sodium azide. For this purpose, $2 \mathrm{~mL}$ of $0.12 \mathrm{~mol} \mathrm{~L}^{-1}$ $\mathrm{MnSO}_{4}$ and $2 \mathrm{~mL}$ of an alkaline solution of sodium azide iodade were added to the incubation flask. The flasks were left to rest for $10 \mathrm{~min}$ and then $2 \mathrm{~mL}$ of concentrated $\mathrm{H}_{2} \mathrm{SO}_{4}$ were added with vigorous agitation. A $100 \mathrm{~mL}$ aliquot of the resultant solution was titrated with 0.0125 mol L-1 $\mathrm{Na}_{2} \mathrm{SO}_{3}$ using a starch solution $0.5 \%(\mathrm{~m} / \mathrm{v})$ as indicator.

The total phosphate concentration in the water samples was determined by the ascorbic acid method in which all forms of phosphorus are converted to phosphate. The sample was digested at $150{ }^{\circ} \mathrm{C}$ with $10 \mathrm{~mL}$ of concentrated $\mathrm{HNO}_{3} / \mathrm{HClO}_{4}(1: 1)$ mixture. The residue obtained was filtered through a Whatman No. 41 filter paper. The combined reagent for the total phosphate determination was added and the absorbance measured at $880 \mathrm{~nm}$ using a light path of $1 \mathrm{~cm}$.

The total ammonia nitrogen content was determined by the distillation and titration procedure. The sample was buffered at $\mathrm{pH} 9.5$ with a borate buffer and distilled into a solution of boric acid. The ammonia in the distillate was determined titrimetrically with standard $\mathrm{H}_{2} \mathrm{SO}_{4}$.

The nitrate concentration was determined by adding $1 \mathrm{~mL}$ of $1 \mathrm{~mol} \mathrm{~L}^{-1} \mathrm{HCl}$ solution to $95 \mathrm{~mL}$ of the water sample obtained by the water filtration through membrane filter. The absorbance of the solution obtained was measured at $220 \mathrm{~nm}$ using a light path of $1 \mathrm{~cm}$. Because dissolved organic matter may also absorb at $220 \mathrm{~nm}$, a second measurement at $275 \mathrm{~nm}$ was made to correct the nitrate value.

The determination of the concentrations of $\mathrm{Al}, \mathrm{Ca}, \mathrm{Cr}$, $\mathrm{Cu}, \mathrm{Fe}, \mathrm{Mg}, \mathrm{Ni}, \mathrm{Pb}$, and $\mathrm{Zn}$ was done in the natural water samples after digesting it with the concentrated acids $\mathrm{HNO}_{3}$ and $\mathrm{HClO}_{4}$, following the procedure recommended for waters containing difficult-to-oxidize organic matter. ${ }^{9}$ With this purpose, aliquots of $10 \mathrm{~mL}$ of concentrated $\mathrm{HNO}_{3} / \mathrm{HClO}_{4}(1: 1)$ mixture were added to $100 \mathrm{~mL}$ of each 
water sample and the resultant mixtures evaporated gently on a hot plate. Further, aliquots of $10 \mathrm{~mL}$ of the acid mixture were added and the resultant mixtures evaporated near dryness. After filtration, the resultant solutions were diluted with deionized water to $25 \mathrm{~mL}$ and the metal concentrations were then determined.

The concentrations of $\mathrm{Al}, \mathrm{Ca}, \mathrm{Cr}, \mathrm{Cu}, \mathrm{Fe}, \mathrm{Mg}, \mathrm{Ni}, \mathrm{Pb}$, and $\mathrm{Zn}$ in the suspended solids were determined as follows: A microwave-assisted digestion of the suspended solids, obtained from the water samples by filtration through a membrane filter of $0.45 \mu \mathrm{m}$ pore size, was done by adding to the samples in a Teflon vessel $6 \mathrm{~mL}$ of $\mathrm{HNO}_{3}(65 \%$, $\mathrm{m} / \mathrm{v}), 1 \mathrm{~mL}$ of $\mathrm{H}_{2} \mathrm{O}_{2}(30 \%, \mathrm{v} / \mathrm{v})$ and $4 \mathrm{~mL}$ of $\mathrm{HF}(40 \%$, $\mathrm{m} / \mathrm{v}$ ). The vessel was closed and heated at $160{ }^{\circ} \mathrm{C}$ in the microwave oven and once the digestion was finished, the reactor was cooled in a water bath before opening. After the filtration step, the extracts were diluted with deionized water to $25 \mathrm{~mL}$ and the metal concentrations were then determined. The procedure was conducted according to the equipment manual.

The concentrations of $\mathrm{Al}, \mathrm{Ca}, \mathrm{Cr}, \mathrm{Fe}, \mathrm{Mg}, \mathrm{Ni}, \mathrm{Cu}, \mathrm{Pb}$, and $\mathrm{Zn}$ were measured with a Varian atomic absorption spectrophotometer (model SpectrAA 200), by direct aspiration of the solutions into the flame. Background correction for the determinations of $\mathrm{Ca}, \mathrm{Fe}, \mathrm{Mg}, \mathrm{Ni}, \mathrm{Pb}$, and $\mathrm{Zn}$ was used. A flame of air-acetylene for $\mathrm{Fe}, \mathrm{Mg}, \mathrm{Ni}$, $\mathrm{Cu}, \mathrm{Pb}$, and $\mathrm{Zn}$ or nitrous oxide-acetylene for $\mathrm{Al}, \mathrm{Ca}$ and $\mathrm{Cr}$ were used. A midpoint check standard and calibration blank at the beginning, end and periodically was analyzed with each group of samples to certify that the instrument calibration has not drifted.

For the nitrate and total phosphate analysis, a UV-Visible HITACHI spectrophotometer, model U-2000, was used. For the BOD determinations, a QUIMIS BOD incubator, model Q-315D, was used. The $\mathrm{pH}$ of the solutions, in the lab, was measured by using a TECNOW pHmeter, model IRIS 7. The dissolved oxygen concentration in the water samples was determined with a portable instrument (HANNA, model HI9142) and the $\mathrm{pH}$, temperature and conductivity were measured at the sampling sites with a portable apparatus (QUIMIS, model Q-410).

A Milestone microwave Laboratory Systems, model Ethos plus, was used for microwave-assisted digestion of samples.

All glassware and materials were cleaned for metal analysis. Certified analytical grade reagents were used throughout. Analytical grade $\mathrm{HNO}_{3}(65 \% \mathrm{~m} / \mathrm{v})$, $\mathrm{HF}(40 \%$, $\mathrm{m} / \mathrm{v})$ and $\mathrm{HClO}_{4}(70 \%, \mathrm{~m} / \mathrm{v})$ were used for digestion. Blanks were run through all experiments to detect any contamination. Three replicates of each water sample were collected an analyzed.

\section{Results and Discussion}

$p H$

The $\mathrm{pH}$ values of the water samples are shown in Figure 2. The $\mathrm{pH}$ values of sites 1,8 and 9 are far from those set by river water standards, i.e., from 6.0 to $9.0 .^{10}$ The low $\mathrm{pH}$ levels can be explained by the local geological characteristics (granite-gneiss complex).
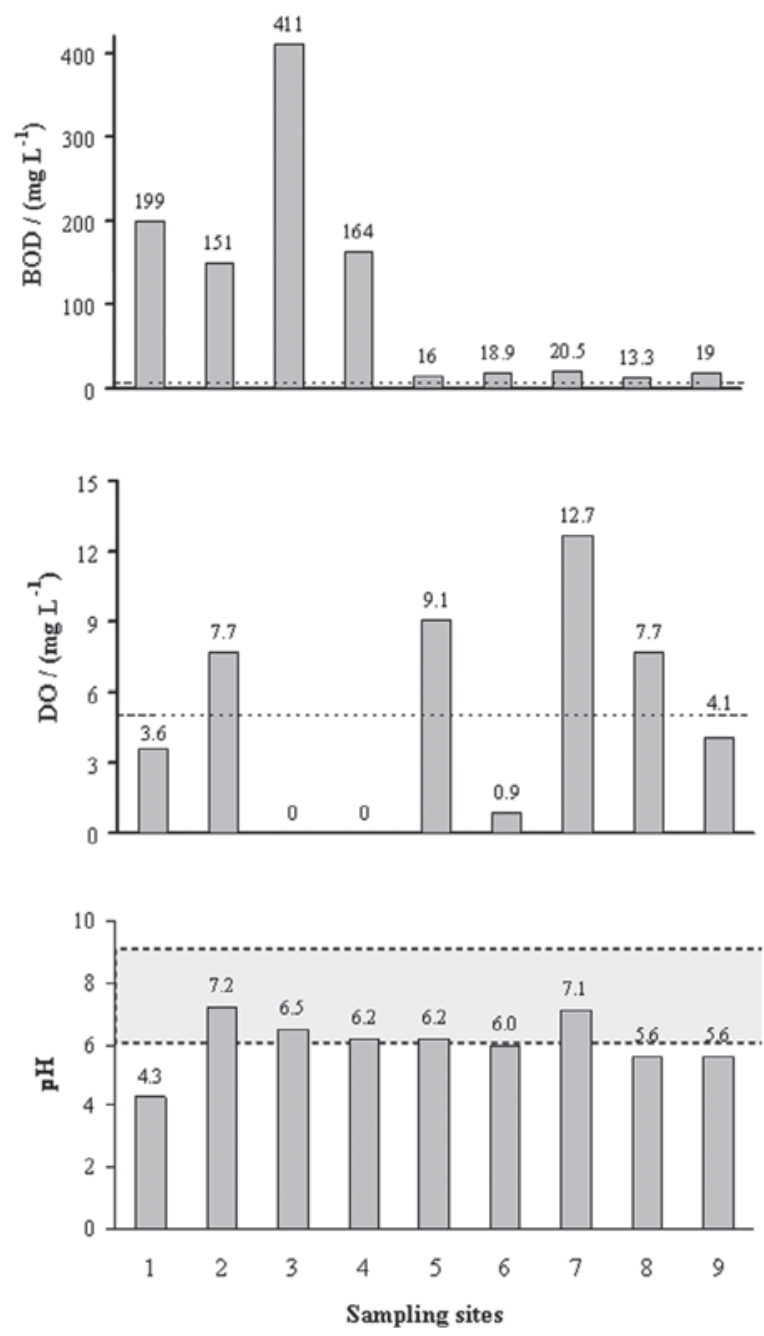

Figure 2. Values of $\mathrm{pH}$, dissolved oxygen (DO) and biochemical oxygen demand (BOD) in the water samples from the São Bartolomeu Stream (samples 1-4), Turvo Sujo River (samples 5-6) and Turvo Limpo River (samples 7-9); - - - lines mean the values of the Brazilian Environmental Standards. ${ }^{10}$

Site 2 is located near a vegetable cultivation area and the stream water from this site is pumped to the water treatment plants of both Viçosa city and the Federal University of Viçosa. In this site, the water $\mathrm{pH}$ (7.2) lay within the permissible values for public health safety. ${ }^{10}$

A relatively low $\mathrm{pH}$ (5.7) was found in the water from a non-contaminated spring (Rochedo site) in Araponga, 
Minas Gerais State, probably due to the presence of acid soils (oxisols) in the region. ${ }^{11}$ Values of $\mathrm{pH}$ from 7.3 to 9.3 were observed in the water of the Ipanema Stream at Ipatinga, Minas Gerais State, that runs through the industrialized region of the Vale do Aço. ${ }^{12}$

\section{Dissolved oxygen}

The measurement of dissolved oxygen concentration allows the evaluation of the aerobic condition of watercourses due to pollutants inputs. The oxygen solubility is a function of temperature, local altitude and water salinity. The levels of dissolved oxygen play an important role in the capacity of natural waters to sustain aquatic life. An appropriate provision of dissolved oxygen is essential for the maintenance of the natural processes of self-depuration in aquatic systems and sewage treatment plants. ${ }^{13}$ Low dissolved oxygen contents indicate the presence of oxidable substances, such as biodegradable organic matter and ions of lower oxidation state as $\mathrm{Fe}$ (II) and $\mathrm{Mn}$ (II). ${ }^{14}$

Figure 2 shows the dissolved oxygen concentrations of the water samples. Sites 1, 3, 4, 6, and 9 showed dissolved oxygen concentrations below the minimum value established by the Brazilian Environmental Standards for Class 2 water, i.e., $5 \mathrm{mg} \mathrm{L}^{-1} .{ }^{10}$ The samples from sites 3 and 4 were practically raw sewage and had no measurable dissolved oxygen. The lower concentrations of dissolved oxygen in the water-courses of sites 3, 4 and 6 may be attributed to the discharges of domestic wastes in locations upstream these sites, which contain a great amount of organic pollution (untreated sewage).

The water sample from site 2 had a relatively high dissolved oxygen concentration $\left(7.7 \mathrm{mg} \mathrm{L}^{-1}\right)$. This is due to the location of site 2 , near a dam from where the water is pumped to a water treatment plant. The favored growth of algae in the dam enhances the production of oxygen at the day light. Even being located close to a region with many houses, site 5 had a relatively high concentration of dissolved oxygen $\left(9.1 \mathrm{mg} \mathrm{L}^{-1}\right)$. This indicates good aeration conditions in a region with strong water flowing and, therefore, with a high degree of oxygen diffusion in the liquid mass.

The low dissolved oxygen concentration in site 6 (Turvo Sujo River) is certainly due to the contribution of organic matter discharge from the São Bartolomeu Stream into its waters, leading to a rapid decrease in the oxygen availability. It seems that the Turvo Sujo River contributes to the increase of the biodegradable organic load of the Turvo Limpo River since the water sample from site 9 had lower dissolved oxygen concentration than that from site 8 .

Figure 2 also shows that the dissolved oxygen concentration in the water sample from site 1 (São Bartolomeu Stream) was $3.6 \mathrm{mg} \mathrm{L}^{-1}$, probably due to the low water flow rate and the use of the site 1 region for husbandry purposes. Low values of dissolved oxygen were reported in the Jaguarí, Jundiaí and Capivarí rivers at the São Paulo State, Brazil, that are used here for comparison. ${ }^{15}$ A water sample from a non-contaminated spring (Rochedo site) in Araponga, Minas Gerais State, presented a DO concentration of $8.1 \mathrm{mg} \mathrm{L}^{-1}{ }^{16}$

\section{Biochemical oxygen demand}

The BOD determination is a measurement of the amount of oxygen required to the oxidation of organic matter by biochemical degradation during a specified incubation period. The greater increase of the BOD values in water are due to organic matter discharges. High organic matter content in water-courses reduces oxygen contents and leads to the loss of aquatic life. High BOD values in water can indicate the increment of micro flora and the appearing of undesirable taste and odor, and can cause clogging of sand filters in water treatment plants. Because the BOD is only a measurement of the amounts of consumed oxygen in a standardized laboratory procedure, the test does not indicate the presence of non-biodegradable matter or the toxic or inhibiting effects of materials on the microbial activity as well.

Figure 2 shows the BOD values found in the water samples. All sites examined in this study presented BOD values above the limit for water quality Class 2 in Brazil, i.e., $5 \mathrm{mg} \mathrm{L}^{-1} .{ }^{10}$ In general, the contaminated sites in the Turvo Sujo River as well as in the Turvo Limpo River had similar BOD values to those of the Nile River in Egypt, which has inferior water quality conditions at the downriver sampling stations. ${ }^{17}$

The enhanced BOD values of the water from sites 1 and 7 were, probably, due to cattle that can act as a source of biodegradable organic matter to the water. The reduced water volume of site 1 also contributed to the organic material enhancement as well as to the BOD content. In site 7 , the influence of the cattle wastes in the BOD values was greater than that of the coffee cultivation, the reason for that is the location of the spring-water in the husbandry area.

The high BOD value (151 $\mathrm{mg} \mathrm{L}^{-1}$ ) found in site 2 was attributed to the great amount of biodegradable biomass (algae) in the water, as well as to the organic matter discharges 
upstream this site. However, the concentration of dissolved oxygen in the same site was high $\left(7.7 \mathrm{mg} \mathrm{L}^{-1}\right)$, indicating recent organic discharges into the stream.

The high BOD values found in sites 3 and 4 were due to sewage discharges from domestic (residential and commercial) sources. The dilution due to the greater water volumes in site 4 as compared to that of site 3 contributed to the reduction in the BOD value in site 4. The natural process of self-depuration in the aquatic environment has also to be taken into account.

The biodegradable organic load discharged into the São Bartolomeu Stream contributed to the increase of the BOD value in the Turvo Sujo River at site 6, as compared with that of site 5. A similar situation was observed in site 9 of the Turvo Limpo River, where the BOD concentration reached $19 \mathrm{mg} \mathrm{L}^{-1}$, as compared with site 8 of the Turvo Sujo River.

\section{Total phosphate}

High concentrations of phosphate in water lead to the eutrophication of a great number of water bodies, mainly lakes and dams. A rapid spreading of organic substances, mostly of algae, is caused by an increase in nutritious substances. As a result, the aquatic life is affected by oxygen depletion levels. ${ }^{13}$

The total phosphate concentrations obtained in the water samples are shown in Figure 3. The water samples of sites 39 showed total phosphate (as P) concentrations higher than the established value by the Brazilian Environmental Standards for water Class 2, i.e., $0.03 \mathrm{mg} \mathrm{L}^{-1} .^{10}$ The high concentrations in the water-courses indicate contamination of the effluents with domestic discharges, which may contain, among other substances, orthophosphate from detergents. Deterioration of water quality has also been observed in the Warche River (Belgium), where tributaries, sewage and dairy effluent flow into the river, inducing significant increase of phosphate, nitrite, nitrate and ammonium concentrations. ${ }^{18}$

\section{Total ammonia nitrogen}

Ammonia $\left(\mathrm{NH}_{3}\right)$ and ammonium $\left(\mathrm{NH}_{4}^{+}\right)$are present naturally in surface water and wastewaters. The ammonia gas is toxic but it is not persistent or cumulative. Because its concentration in waters is usually low, the total ammonia nitrogen $\left(\mathrm{NH}_{3}+\mathrm{NH}_{4}^{+}\right)$does not cause any physiologic damage to the human beings and animals. ${ }^{13}$ Figure 3 shows the total ammonia nitrogen concentrations in the water samples. Samples 3 and 4 showed high total ammonia nitrogen concentrations as compared to the maximum limit value established by the Brazilian Environmental Standards, i.e., $3.7 \mathrm{mg} \mathrm{L}^{-1}$ for waters with $\mathrm{pH}<7.5{ }^{10}$
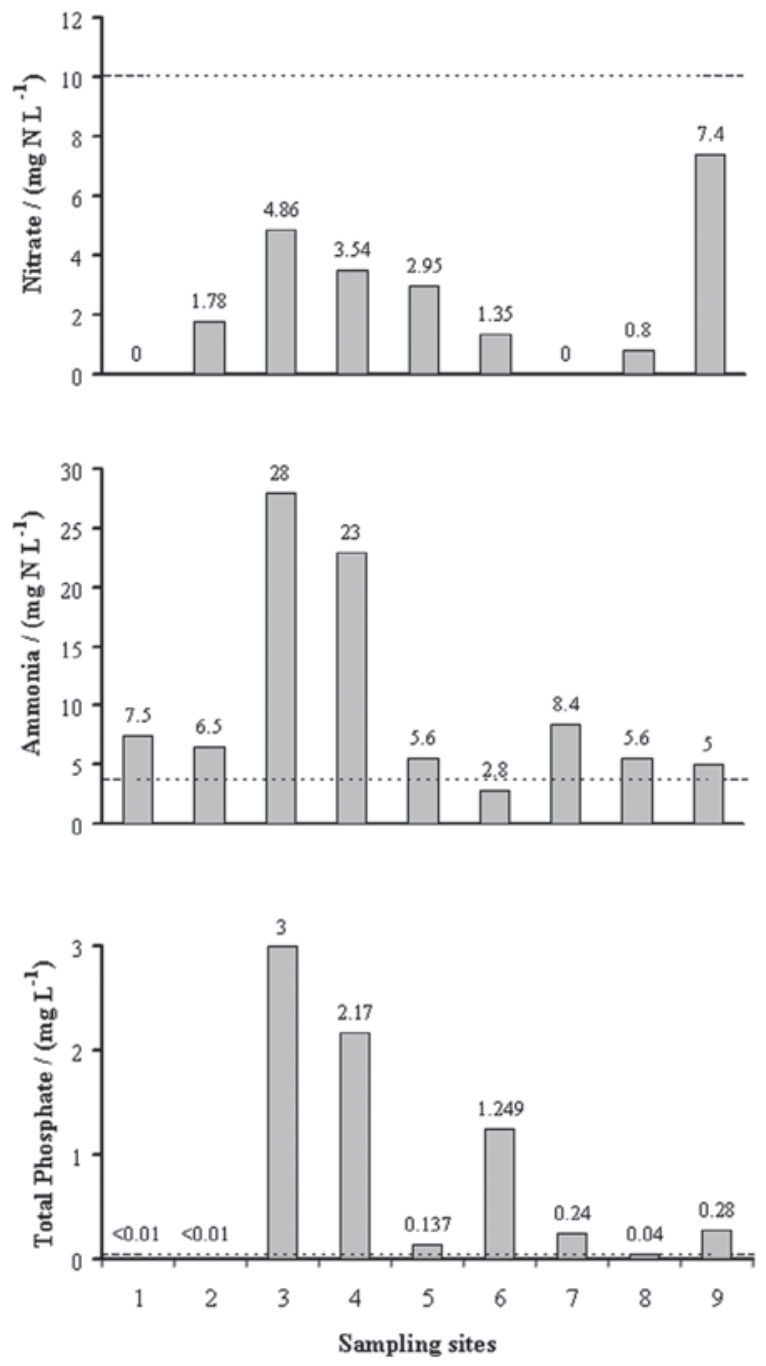

Figure 3. Total phosphate, total ammonia nitrogen and nitrate concentrations in the water samples from the São Bartolomeu Stream (samples 1-4), Turvo Sujo River (samples 5-6) and Turvo Limpo River (samples 7-9); - - lines mean the values of the Brazilian Environmental Standards. ${ }^{10}$

While the source of water contamination in site 1 was the urine of animals, in the site 7 was the use of fertilizers containing ammonium salts such as nitrate or sulfate. In the other sites, the source of contamination was the discharge of domestic sewage, since these sites are located in areas receiving high loads of sewage from Viçosa and Paula Cândido cities.

The total ammonia nitrogen concentrations in the water samples examined in this work were 5-50 times higher than the value reported for the Piracicaba River that runs through an industrialized region at the São Paulo State. ${ }^{15}$ High total ammonia nitrogen, biochemical oxygen demand and phosphate concentrations were reported for surface water accumulated in a landfill area at the rainy season, ${ }^{19}$ with levels 
beyond the Class 2 standards established by the Brazilian Legislation. ${ }^{10}$

\section{Nitrate}

Nitrate is the main inorganic form of nitrogen in watercourses and in contaminated waters the main source of nitrate is human and animal dejections. Nitrate stimulates plant growth and has considerable influence on the bloom of aquatic organisms such as algae. ${ }^{13}$ The data from nitrate concentrations are presented in Figure 3. All sites had nitrate values below that one allowed for public health, i.e., $10 \mathrm{mg} \mathrm{L}^{-1} .{ }^{10} \mathrm{In}$ most sites there was an increase in the nitrate concentration as compared with that of site 1 . This could be attributed to the organic matter present in the domestic sewage discharges, since one of the sources of the $\mathrm{NO}_{3}^{-}$ions is the $\mathrm{N}$ from the biodegradable organic matter. $^{14}$

In general, the nitrate concentrations were below those of the total ammonia nitrogen. This indicates that the nitrogen in the water-courses was originated mainly from the recent sewage discharges, since there was no larger mineralization with nitrate ions formation. In waters and wastewaters the forms of nitrogen are, in order of decreasing oxidation state, nitrate, nitrite, ammonia, and organic nitrogen. ${ }^{9}$

The nitrate concentrations in the waters of the Timotinho Stream, that flows close to a smeltery in Timóteo at Minas Gerais State, were higher downstream than upstream. ${ }^{20}$ This was due to the discharge of effluents contaminated with nitrate into the stream, since the use of $\mathrm{a} \mathrm{HNO}_{3} / \mathrm{HF}$ mixture in the pickling process of steel production has been a common practice. In the Tubarão River at the Santa Catarina State in Brazil, the nitrate concentration varied from non-detected up to $0.051 \mathrm{mg}$ $\mathrm{L}^{-1}$. This river flows through mining areas and waste disposal from charcoal processing. The relatively low nitrate concentration in the Tubarão River indicates that the region is not being contaminated with this pollutant. ${ }^{21}$

\section{Metals in water}

Metal concentrations for the water-courses examined are shown in Table I. Aluminium, though not a heavy metal, it was included in this work due to its toxicity to plants, humans and fishes. It is well known that Al restrains plant growth mainly in acid soils, being very severe in soils with $\mathrm{pH}$ below 5 and occasionally in soils of higher $\mathrm{pH} .{ }^{22}$ Aluminum is present in the brain tissues of human body at concentration close to $2 \mathrm{mg} \mathrm{g}^{-1}$ and when present in high concentrations it can cause deleterious effects such as memory damage and convulsions. ${ }^{23}$ In addition, there are some evidences that $\mathrm{Al}$ is involved in the Alzheimer disease. ${ }^{24}$ Aluminum can lead to heavy loss of electrolytes, extreme gill damage and circulating collapse in fish. ${ }^{25}$

In general, the samples examined in this work showed enhanced $\mathrm{Al}$ concentration (Table 1). It should be taken into account that the studied water-courses run through a region of acidic soils with low $\mathrm{pH}$ and high exchangeable acidity.

Site 4 showed Al concentration higher than the other sites examined due to waste inputs into the São Bartolomeu Stream, which come from the disposal of municipal garbage, metallic scraps and civil architecture residues in the neighborhood of this site. The maximum limit established by the Brazilian Environmental Standards of dissolved Al for Class 2 water is $100 \mu \mathrm{g} \mathrm{L}^{-1} .{ }^{10}$ An average $\mathrm{Al}$ concentration of $380.5 \mu \mathrm{g} \mathrm{\textrm {L } ^ { - 1 }}$ in the Doce River, which

Table 1. Metal concentrations in the collected waters digested with $\mathrm{HNO}_{3} / \mathrm{HClO}_{4}$ mixture

\begin{tabular}{|c|c|c|c|c|c|c|c|c|c|}
\hline \multicolumn{10}{|c|}{$\operatorname{Mean}^{\mathrm{a}} \pm \mathrm{SD} /\left(\mathrm{mg} \mathrm{L}^{-1}\right)$} \\
\hline Site & $\mathrm{Al}$ & $\mathrm{Ca}$ & $\mathrm{Cr}$ & $\mathrm{Cu}$ & $\mathrm{Fe}$ & $\mathrm{Mg}$ & $\mathrm{Ni}$ & $\mathrm{Pb}$ & $\mathrm{Zn}$ \\
\hline $\mathrm{LEC}^{\mathrm{t}}$ & issolved: 100 & - & Total: 50 & Dissolved: 9 & Dissolved: 300 & - & Total: 25 & Total: 10 & Total: 180 \\
\hline \multicolumn{10}{|c|}{ São Bartolomeu Stream } \\
\hline 1 & $310 \pm 14$ & $1120 \pm 118$ & $13.0 \pm 0.3$ & $0.7 \pm 0.2$ & $598 \pm 4$ & $514 \pm 4$ & $15.5 \pm 2.5$ & $22.5 \pm 0$ & $10.5 \pm 2.5$ \\
\hline 2 & $10.0 \pm 0.5$ & $1970 \pm 70$ & $22.5 \pm 2.1$ & $<0.5^{\mathrm{c}}$ & $127 \pm 6$ & $1100 \pm 90$ & $7.8 \pm 0.2$ & $<3$ & $<1$ \\
\hline 3 & $104 \pm 6$ & $8130 \pm 210$ & $38.6 \pm 1.9$ & $4.8 \pm 0$ & $1800 \pm 140$ & $3410 \pm 150$ & $13.0 \pm 1.5$ & $14.2 \pm 1.0$ & $34.1 \pm 3.4$ \\
\hline 4 & $1480 \pm 3$ & $800 \pm 3$ & $7.6 \pm 1.1$ & $4.2 \pm 0.3$ & $2550 \pm 20$ & $2280 \pm 50$ & $7.1 \pm 0.3$ & $7.7 \pm 0.2$ & $27.5 \pm 0.3$ \\
\hline \multicolumn{10}{|c|}{ Turvo Sujo River } \\
\hline 5 & $137 \pm 10$ & $1610 \pm 1$ & $<2$ & $<0.5$ & $551 \pm 42$ & $980 \pm 80$ & $<1$ & $<3$ & $<1$ \\
\hline 6 & $111 \pm 9$ & $5530 \pm 260$ & $3.5 \pm 0.3$ & $1.0 \pm 0.05$ & $1240 \pm 70$ & $1370 \pm 30$ & $6.0 \pm 0.2$ & $3.8 \pm 0.4$ & $300 \pm 8$ \\
\hline \multicolumn{10}{|c|}{ Turvo Limpo River } \\
\hline 7 & $459 \pm 45$ & $940 \pm 84$ & $<2$ & $<0.5$ & $3040 \pm 180$ & $590 \pm 60$ & $<1$ & $<3$ & $1.4 \pm 0.1$ \\
\hline 8 & $111 \pm 11$ & $1270 \pm 60$ & $3.3 \pm 0.3$ & $<0.5$ & $598 \pm 8$ & $678 \pm 16$ & $3.4 \pm 0.1$ & $<3$ & $4.8 \pm 0.8$ \\
\hline 9 & $480 \pm 50$ & $4290 \pm 60$ & $2.6 \pm 0.2$ & $2.7 \pm 0.3$ & $1340 \pm 60$ & $1290 \pm 30$ & $10.4 \pm 0.4$ & $4.0 \pm 0.3$ & $7.4 \pm 0.3$ \\
\hline
\end{tabular}

${ }^{a}$ Mean of three replicates \pm standard deviation. ${ }^{b}$ Legally established concentration. ${ }^{10}$ 'Values preceded by $<$ symbol indicate detection limit. 
transverses the industrialized area of the Vale do Aço (Steel Valley) at the Minas Gerais State has been reported. ${ }^{26}$

The wastewater treatment of a kaolin industry in Vermelho Novo at the Minas Gerais State was not adequate to avoid metal discharges into the Vermelho Stream. Aluminum is a component of kaolin and the authors found that the $\mathrm{Al}$ concentrations in its waters varied from 210 to 4,760 $\mu \mathrm{g} \mathrm{\textrm {L } ^ { - 1 }} .^{11}$

The lower metal concentrations in the water sample of site 2 as compared with that of site 1 were probably due to the their retention by the sediment. The dam in site 2 might provide a suitable sink for metals in this site.

The enhanced $\mathrm{Ca}$ and $\mathrm{Mg}$ concentrations in the water samples from sites 3,6 and 9 can be mainly due to soil liming to improve soil $\mathrm{pH}$ near these sites, where bean and lettuce are cultivated.

The relatively high $\mathrm{Fe}$ concentrations in the waters from most sites were due to the presence of iron oxides in the soils which were drained by these waters. The highest Fe concentration $\left(3,040 \mathrm{mg} \mathrm{L}^{-1}\right)$ was found in the springwater collected in site 7 of the Turvo Limpo River, being 5 times larger than the value found in site 1 . A value of $843 \mu \mathrm{g} \mathrm{L}^{-1}$ of $\mathrm{Fe}$ for a spring in the São Bartolomeu Stream has been reported. ${ }^{27}$ Heavy metal contamination has been found in the waters of the Paraíba do Sul River, where Fe concentration reached $1,400 \mu \mathrm{g} \mathrm{L^{-1 }} \cdot{ }^{28}$ Iron is an element which may lead to heavy corrosion in pipe lines in the presence of microorganisms. This element may also stain cloths and ceramics. ${ }^{29}$

Site 6 at Turvo Sujo River showed Zn concentration higher than the other sites examined. The concentration found in this site ( $300 \mu \mathrm{g} \mathrm{L}^{-1}$ of $\mathrm{Zn}$ ) was similar to that reported for the Muriaé River that transverses an industrialized area at the Minas Gerais State, ${ }^{30}$ and can be probably due to the disposal of municipal garbage near this site.

Zinc concentrations varying from 48 to $1.820 \mu \mathrm{g} \mathrm{L}^{-1}$ were previously reported for the Ubá Stream in Brazil, which runs near the vicinity of an electroplating industry. ${ }^{31}$

The $\mathrm{Pb}$ concentration ranged from not detectable $(<3$

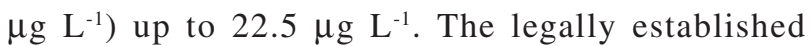
concentration in Brazil for Class 2 water is $10 \mu \mathrm{g} \mathrm{L}^{-1}$ of $\mathrm{Pb} .{ }^{10}$ In Germany, early investigations of metal levels in the highly polluted Rhine River showed that $\mathrm{Pb}$ concentration reached up to $57 \mathrm{mg} \mathrm{L}^{-1}$, which exceed the maximum limit recommended for raw or drinking water, established by the World Health Organization. ${ }^{32}$

The $\mathrm{Cr}$ concentrations ranged from not detectable $(<2$ $\mu \mathrm{g} \mathrm{L}^{-1}$ ) up to $38.6 \mu \mathrm{g} \mathrm{L}^{-1}$, while the maximum limit established by the Brazilian Environmental Standards for water Class 2 is $50 \mu \mathrm{g} \mathrm{L}{ }^{-1}$ of $\mathrm{Cr}^{10}{ }^{10}$ Two typical examples of non-polluted rivers are the Amazon River (Brazil) and the Skeleton River (Oklahoma, USA). While the dissolved Cr concentration showed an average of $2 \mu \mathrm{g} \mathrm{L}^{-1}$ in the former, ${ }^{33}$ values ranging from 0.3 to $3.5 \mu \mathrm{g} \mathrm{L}^{-1}$ were found in the latter. ${ }^{34}$ It has been reported that intensive exposure to $\mathrm{Cr}$ compounds may lead to lung cancer in man. ${ }^{35}$

\section{Metals in suspended solids}

Analysis of suspended solids provides data on the metal content and transport along water-courses, being a good experimental approach for indicating that metal contamination can be found far from the emission sources. ${ }^{36}$ Reports on the Acari-São João de Meriti River System, Brazil, have shown that the transport of heavy metals occurs via the particulate phase where mobile forms of metals prevail. ${ }^{37}$ The Mississippi River (USA) carries a thousand times more $\mathrm{Fe}$ in the suspended solids than in the dissolved fraction. ${ }^{38}$ According to the metal investigations, ${ }^{31}$ a large fraction of $\mathrm{Fe}, \mathrm{Zn}$ and $\mathrm{Cd}$ was transported with the suspended solids in the Ubá Stream at the Minas Gerais State, which runs close to an electroplating industry. The studies on the transport and availability of heavy metals in the Paraíba do Sul-Guandú River System in the State of Rio de Janeiro, Brazil, have showed that the organic matter is the main vehicle in the transport of metals in the examined aquatic system. ${ }^{28}$

Metal concentrations for suspended solids from the study region are shown in Table 2. Sites 3, 4 and 6 showed $\mathrm{Cu}$ and $\mathrm{Zn}$ concentrations in the suspended solids higher than the global average, ${ }^{39}$ while $\mathrm{Cr}$ and $\mathrm{Pd}$ had enhanced concentrations in several samples. This can be explained by the anthropogenic activities. The suspended solids collected downstream the effluent discharges of domestic (residential and commercial) activities showed, in general, enhanced metal concentrations. The high metal concentrations found in the suspended solids from site 4 might be attributed to the disposal of municipal garbage, metallic scraps and civil architecture residues in the neighborhood of this site. The highest $\mathrm{Al}, \mathrm{Ca}, \mathrm{Cr}, \mathrm{Cu}$, $\mathrm{Mg}, \mathrm{Ni}$, and $\mathrm{Pb}$ concentrations were found in site 4 .

As expected, the suspended solids collected in site 6 had higher metal concentrations than that of site 5, which is located upstream the junction of the São Bartolomeu Stream with the Turvo Sujo River.

When $\mathrm{Al}, \mathrm{Cr}, \mathrm{Fe}, \mathrm{Pb}$, and $\mathrm{Zn}$ concentrations in suspended solids are compared with those from the industrialized regions of Ouro Branco (Passagem Stream) and Conselheiro Lafaiete (Ventura Luís River) in the Minas Gerais State, ${ }^{16}$ elevated values are generally observed. For example, site 4 showed $\mathrm{Zn}$ concentration above sixty times 
Table 2. Metal concentrations in the suspended particles

\begin{tabular}{|c|c|c|c|c|c|c|c|c|c|}
\hline \multicolumn{10}{|c|}{$\mathrm{Mean}^{\mathrm{a}} \pm \mathrm{SD} /\left(\mathrm{mg} \mathrm{kg}^{-1}\right.$, dry matter $)$} \\
\hline Site & $\mathrm{Al}$ & $\mathrm{Ca}$ & $\mathrm{Cr}$ & $\mathrm{Cu}$ & $\mathrm{Fe}$ & $\mathrm{Mg}$ & $\mathrm{Ni}$ & $\mathrm{Pb}$ & $\mathrm{Zn}$ \\
\hline \multicolumn{10}{|c|}{ São Bartolomeu Stream } \\
\hline 1 & $231100 \pm 1800$ & $52320 \pm 2200$ & $80 \pm 1$ & $4.71 \pm 0.3$ & $82300 \pm 4900$ & $1830 \pm 100$ & $<0.5^{\mathrm{b}}$ & $450 \pm 30$ & $<0.5$ \\
\hline 2 & $421600 \pm 2100$ & $148600 \pm 100$ & $130 \pm 2$ & $9.03 \pm 0.9$ & $38800 \pm 600$ & $2530 \pm 120$ & $76.0 \pm 0$ & $<0.5$ & $<0.5$ \\
\hline 3 & $514000 \pm 3300$ & $155600 \pm 4200$ & $51.7 \pm 0.2$ & $144 \pm 7$ & $59000 \pm 2500$ & $2090 \pm 30$ & $86.0 \pm 1$ & $220 \pm 8$ & $1390 \pm 20$ \\
\hline 4 & $1929000 \pm 6500$ & $500000 \pm 2800$ & $830 \pm 13$ & $2020 \pm 100$ & $111100 \pm 3500$ & $8820 \pm 220$ & $572 \pm 12$ & $3590 \pm 150$ & $6640 \pm 660$ \\
\hline \multicolumn{10}{|c|}{ Turvo Sujo River } \\
\hline 5 & $40440 \pm 570$ & $90700 \pm 2900$ & $219 \pm 15$ & $21 \pm 1$ & $26700 \pm 600$ & $2420 \pm 230$ & $68.6 \pm 1.4$ & $73.5 \pm 3$ & $246 \pm 26$ \\
\hline 6 & $53800 \pm 3200$ & $149000 \pm 1930$ & $321 \pm 29$ & $125 \pm 9$ & $240800 \pm 2500$ & $7720 \pm 270$ & $161 \pm 11$ & $890 \pm 60$ & $15350 \pm 200$ \\
\hline \multicolumn{10}{|c|}{ Turvo Limpo River } \\
\hline 7 & $6780 \pm 740$ & $7240 \pm 910$ & $22.4 \pm 8.0$ & $<0.2$ & $20170 \pm 70$ & $530 \pm 40$ & $13.0 \pm 0.1$ & $31.6 \pm 1.6$ & $7.5 \pm 0.1$ \\
\hline 8 & $7770 \pm 220$ & $51300 \pm 3100$ & $206 \pm 1.3$ & $33.0 \pm 2$ & $20560 \pm 120$ & $910 \pm 70$ & $113 \pm 5$ & $189 \pm 13$ & $211 \pm 8$ \\
\hline 9 & $52400 \pm 4100$ & $21170 \pm 340$ & $13.7 \pm 1.9$ & $<0.2$ & $13960 \pm 50$ & $180 \pm 20$ & $<0.5$ & $<0.5$ & $<0.5$ \\
\hline
\end{tabular}

${ }^{\mathrm{a}}$ Mean of three replicates \pm standard deviation. ${ }^{\text {b }}$ Values preceded by $<$ symbol indicate detection limit.

higher than the value observed in the Passagem Stream, and above thirty five times that of Ventura Luis Stream. However, others workers reported that the transport of $\mathrm{Cu}, \mathrm{Cr}, \mathrm{Ni}, \mathrm{Pb}$, and $\mathrm{Zn}$ in suspended solids were higher in industrialized areas than those of non-industrialized areas. ${ }^{28}$ The $\mathrm{Zn}$ concentrations in suspended solids collected from the Vermelho Stream that runs close to a kaolin processing plant at the Minas Gerais State reached $535 \mathrm{mg} \mathrm{kg}^{-1} .40$

Very high $\mathrm{Cr}$ concentrations (from 41 to $3,400 \mathrm{mg}$ $\mathrm{kg}^{-1}$ ) were found in suspended solids around the mouths of the Besós River and the pipeline of the Barcelona-Besós wastewater treatment plant in Spain. ${ }^{41}$ In a region of leather tanning industries in Brazil, the chromium concentrations in the suspended solids were as high as $4,700 \mathrm{mg} \mathrm{kg}^{-1}$ in the Ubá Stream, and $11,000 \mathrm{mg} \mathrm{kg}^{-1}$ in the Patusca Stream. ${ }^{12}$ In the present study, the concentration of this element ranged from 13.7 to $830 \mathrm{mg} \mathrm{kg}^{-1}$.

Site 8 showed enhanced metal concentrations in the suspended solids as compared with those of site 7 , and it can be attributed to a greater load of contaminants in the Turvo Limpo River due to untreated domestic sewage discharge, as compared to that of site 7 . Site 7 is located in a rural area and close to a spring and the main activities include cattle and coffee production.

The suspended solids from site 9 had lower metal concentration than that of site 6 , which is located upstream the junction of the Turvo Sujo River with the Turvo Limpo River.

\section{Conclusions}

This study intended to identify the hot spots for pollutant discharges by untreated or inadequately treated municipal sewage into the examined aquatic system. The influence on the water quality due to husbandry, agriculture and the disposal of municipal garbage, metallic scraps and civil architecture residues in the neighborhood of this site was also examined. The data obtained were compared with the values established by the Brazilian Environmental Standards.

The results of this work indicate that the water-courses examined receive wastes and become enriched by $\mathrm{Zn}$ and $\mathrm{Pb}$. The $\mathrm{Zn}$ and $\mathrm{Pb}$ concentrations in the river waters are found to be up to 1.7 times and 2.2 times, respectively, higher than the legally established concentrations for Class 2 water. The suspended solids collected downstream the effluent discharges of domestic (residential and commercial) activities show, in general, enhanced metal concentrations. Some sites presents $\mathrm{Cu}$ and $\mathrm{Zn}$ concentrations in the suspended solids higher than the global average, while $\mathrm{Cr}$ and $\mathrm{Pb}$ have enhanced concentrations in several samples.

The results also indicate that the studied regions must be monitored as metal, $\mathrm{pH}, \mathrm{OD}, \mathrm{BOD}$, total phosphate and total ammonia nitrogen levels in water samples are far from those set by the Brazilian Environmental Standards, or are comparable with other contaminated areas.

\section{Acknowledgment}

We thank the Brazilian National Research Council (CNPq, Brazil) for finantial support.

\section{References}

1. Harrison, R. M.; Understanding our Environment: An Introduction to Environmental Chemistry and Pollution, The Royal Society of Chemistry: London, 1995. 
2. IBGE: Pesquisa Nacional de Saneamento Básico, Instituto Brasileiro de Geografia e Estatística: Brasil, 2001.

3. Baeta, C.; Revista Estado de Minas 2002, 46, 16.

4. Moore, J. W.; Moore, E. A.; Environmental Chemistry, Academic Press, Inc.: London, 1976.

5. Gibbs, R.; Geol. Soc. Am. Bull. 1977, 88, 829.

6. Souza, H. N.; Monografia, Universidade Federal de Viçosa, Brazil, 1999.

7. Vilela, M.; MSc. Dissertation, Universidade Federal de Viçosa, Brazil, 1998.

8. Baruqui, F. M.; MSc. Dissertation, Universidade Federal de Viçosa, Brazil, 1982.

9. APHA; Standard Methods for the Examination of Water and Wastewater, 20 $0^{\text {th }}$ ed., American Public Health Association: Washington, 1998.

10. CONAMA: Resolução No. 357, Conselho Nacional do Meio Ambiente, Ministério do Meio Ambiente: Brasília, Brazil, 2005.

11. Jordão, C. P.; Pereira, M. G.; Pereira, J. L.; Toxicol. Environ. Chem. 2001, 82, 139.

12. Jordão, C. P.; Silva, A. C.; Pereira, J. L.; Brune, W.; Quim. Nova 1999, 22, 47.

13. CETESB: Relatório de Qualidade das Águas Interiores do Estado de São Paulo 2000, Companhia de Tecnologia e Saneamento Ambiental: São Paulo, Brazil, 2001.

14. Von Sperling, M.; Introdução à Qualidade das Águas e ao Tratamento de Esgotos, Segrac: Belo Horizonte, Brazil, 1996.

15. CETESB; Relatório de Qualidade das Águas Interiores do Estado de São Paulo 1998, Companhia de Tecnologia e Saneamento Ambiental: São Paulo, Brazil, 1999.

16. Jordão, C. P.; Pereira, M. G.; Bellato, C. R.; Pereira, J. L.; Matos, A. T.; Environ. Monit. Assess. 2002, 79, 75.

17. Abdelhamid, M. I.; Shaabandessouki, S. A.; Skulberg, O. M.; Arch. Hydrobiol. 1992, 3, 283.

18. Marneffe, Y.; Comblin, S.; Bussers J. C.; Thome, J. P.; Neth. J. Zool. 1996, 46, 337.

19. Kuajara, O.; Sanchez, J. C. D.; Ballestrin, R. A.; Teixeira, E. C.; Water Environ. Res. 1997, 69, 1170.

20. Pires, C. K.; MSc. Dissertation, Universidade Federal de Viçosa, Brazil, 1999.

21. Klug, M.; Lima, M. C.; Gotardo, H.; Bortoluzzi, I. P.; Dalmônico, A. L.; Martins, A.; Abstracts of the $22^{a}$ Reunião Anual da Sociedade Brasileira de Química, Poços de Caldas, Brazil, 1999.
22. Fahl, J. I.; Carelli, M. L. C.; Deuber, R.; Nogueira, S. S. S.; Hiroce, R.; Rev. Bras. Cienc. Solo 1982, 6, 203.

23. Shimma, E. M. I.; Nutrição - Nosso Corpo Mineral, Globo Ciência: Rio de Janeiro, Brazil, 1995, 5, 33.

24. Alloway, B. J.; Ayres, D. C.; Chemical Principles of Environmental Pollution, Blackie A \& P.: London, 1994.

25. Savory, J.; Wills, M. R. In Metals and Their Compounds in the Environment; Merian, E., ed., VCH Verlagsgesellschaft: Weinheim, 1991, ch. II.1.

26. Jordão, C. P.; Pereira, J. C.; Brune, W.; Pereira, J. L.; Braathen, P. C.; Environ. Technol. 1996, 17, 489.

27. Jordão, C. P.; Pereira, M. G.; Pereira, J. L.; Bellato, C. R.; An. Assoc. Bras. Quim. 2000, 49, 31.

28. Malm, O.; Pfeiffer, W. C.; Fiszman, M.; Azcue, J. M.; Sci. Total Environ. 1988, 75, 201.

29. Gentil, V.; Corrosão, Publicações Almeida Neves - Editores Ltda.: Rio de Janeiro, Brazil, 1970.

30. Jordão, C. P.; Pereira, M. G.; Pereira, J. L.; Water, Air, Soil Pollut. 2002, 140, 119.

31. Silva, A. C.; Jordão, C. P.; Pereira, J. L.; Viana, R. F.; Revista Escola de Minas 1999, 52, 94.

32. Salomons, W.; Förstner, U.; Metals in the Hydrocicle, SpringerVerlag: Berlin Heidelberg, 1984.

33. Förstner, U.; Wittmann, G. T. W.; Metal Pollution in the Aquatic Environment, Springer-Verlag: New York, 1981.

34. Namminga, H.; Wilhm, J.; Journal Water Pollution Control Federation 1977, 49, 1725.

35. Gebhart, E.; Rossman, G. In Metals and Their Compounds in the Environment; Merian, E., ed.; VCH Verlagsgesellschaft: Weinheim, 1991, ch. I., p.18.

36. Morrison, G. M.; Whei, M. C.; Anal. Proc. 1991, 28, 70.

37. Rego, V. S.; Pfeiffer, W. C.; Barcellos, C. C.; Rezende, C. E.; Malm, O.; Environ. Technol. 1993, 14, 167.

38. Taylor, H. E.; Shiller, A. M.; Environ. Sci. Technol. 1995, 29 , 1313.

39. Martin, J. M.; Meybeck, M.; Marine Chemistry 1979, 7, 173.

40. Jordão, C. P.; Pereira, M. G.; Matos, A. T.; Pereira, J. L.; J. Braz. Chem. Soc. 2005, 16, 241.

41. Palanques, A.; Environ. Monit. Assess. 1994, 85, 205.

Received: April 6, 2006

Web Release Date: November 24, 2006 